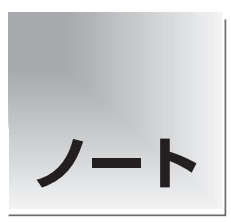

論文受付

2015 年 6 月 16 日

論文受理

2015 年 12 月 24 日

Code No. 812

\section{$\mathrm{X}$ 線 CT 装置の半価層測定における 非接続形 X 線出力アナライザ専用鉛ケースの開発}

\author{
赤石泰一 ${ }^{1}$ 武田浩光 ${ }^{2}$ 金澤仁幸 ${ }^{1}$ 吉井勇治 $^{1}$ 浅沼 治 ${ }^{2}$ \\ ${ }^{1}$ 札幌医科大学医学部教育研究機器センター \\ 2 札幌医科大学附属病院放射線部
}

\section{緒 言}

2004 年, Gonzalez ら ${ }^{1)}$ がX 線診断の被ばくによっ てがんの発生する確率を推計した結果, 日本は先進 15 カ国の中で最も高いと報告された。更に, 2011 年には 東北地方太平洋沖地震に伴う福島第一原子力発電所事 故が起こり，一般公衆の放射線被ばくに対する関心が 高まっている 2015 年 6 月には医療被ばく研究情報 ネットワーク (Japan Network for Research and Information on Medical Exposures: J-RIME) から, 日 本としての診断参考レベル (diagnostic reference levels: DRL)が公表され，今後はより一層，医療被ばく管
理の重要性が増すと考えられる。

特に, computed tomography (CT) 検査による被ば く線量は, 医療被ばくの中で占める割合が最も多く, わが国の国民 1 人あたりの年間被ばく線量が 5.3 $\mathrm{mSv} /$ 年であるのに対して, CT 検査による年間被ばく 線量は $2.3 \mathrm{mSv} /$ 年であり, 全体の $43 \%$ を占めると報 告されている ${ }^{3)}$. このため, CT 検査における線量評 価, 被ばく管理を行うことが重要である.

CTの線量評価における指標としては, multiple scan average dose $(\operatorname{MSAD}[\mathrm{Gy}])^{4)}$, CT dose index $(\mathrm{CTDI}[\mathrm{Gy}])^{5)}$, dose length product $(\mathrm{DLP}[\mathrm{Gy} \cdot \mathrm{cm}])^{6)}$,

\title{
Development of a Lead-covered Case for a Wireless X-ray Output Analyzer to Perform CT Half-value Layer Measurements
}

\author{
Hirokazu Akaishi, ${ }^{1 *}$ Hiromitsu Takeda, ${ }^{2}$ Yoshiyuki Kanazawa, ${ }^{1}$ Yuji Yoshii, ${ }^{1}$ and Osamu Asanuma ${ }^{2}$ \\ ${ }^{1}$ Biomedical Research, Education and Instrumentation Center, Sapporo Medical University \\ ${ }^{2}$ Division of radiology and Nuclear Medicine, Sapporo Medical University Hospital
}

Received June 16, 2015; Revision accepted December 24, 2015

Code No. 812

\section{Summary}

Measurement of the half-value layer (HVL) is a difficult task in computed tomography (CT), because a nonrotating X-ray tube must be used. The purpose of this study is to develop a lead-covered case, which enables HVL measurements with a rotating CT X-ray tube. The lead-covered case was manufactured from acrylic and lead plates, which are $3 \mathrm{~mm}$ thick and have a slit. The slit-detector distance can be selected between $14 \mathrm{~mm}$ and $122 \mathrm{~mm}$. HVL measurements were performed using a wireless X-ray output analyzer "Piranha." We used the following exposure conditions: tube voltages of 80,100 , and $120 \mathrm{kV}$; a tube current of $550 \mathrm{~mA}$; and an exposure time of $1.0 \mathrm{~s}$. The HVLs were measured by using the following two methods: (a) Nonrotating method-a conventional method that uses the nonrotating exposure mode. (b) Rotating method-a new method that uses the lead-covered case and the rotating exposure mode. As a result, when the slit-detector distance was $58 \mathrm{~mm}$, the HVL values obtained by the nonrotating and rotating methods were 4.38 and $4.24 \mathrm{mmAl}$ at $80 \mathrm{kV}, 5.51$ and $5.37 \mathrm{mmAl}$ at $100 \mathrm{kV}, 6.61$ and 6.48 $\mathrm{mmAl}$ at $120 \mathrm{kV}$, respectively. A lead-covered case, which enables the measurement of the HVL in a rotating X-ray tube, was developed. The case is useful in measuring the HVLs at facilities that cannot fix the X-ray tube.

Key words: computed tomography (CT), half-value layer (HVL), lead-covered case, effective energy, semiconductor detector

\footnotetext{
* Proceeding author
} 
size-specific dose estimates $(\mathrm{SSDE}[\mathrm{Gy}])^{7)}$ などが用い られる。しかし，これらの線量指標は空気カーマに基 づいた值であり，実効線量や吸収線量を意味するもの ではない。人体に扔ける被ばく線量をより詳細に評価 するうえでは, 臓器, 組織レベルにおける吸収線量を 把握することが望ましい8)，そのためには，人体ファ ントム内に配置した線量計を用いて測定した照射線量 に, 組織の吸収線量変換係数を乗じる必要がある。こ の吸収線量変換係数は線質に応じて変化するため, 実 効エネルギー測定が必要不可欠となる9).

一般撮影装置における実効エネルギー測定の方法と しては, アルミニウム板または銅板を用いて減弱曲線 を作成して得られた半価層から線減弱係数を求めて算 出する方法が一般的である10,11). しかし，この方法を CT 装置に応用するためには, メーカ側の協力のもと, メンテナンスモードによって CT 装置の X 線管を固 定しX 線を照射(固定照射)する必要があるため, 容 易に測定することができなかった ${ }^{12)}$.

そこで，CT 装置の実効エネルギー測定の簡便法と して, X 線管の固定を必要としないアルミリング法 ${ }^{13)}$ や鉛ケース法 ${ }^{12,14,15)}$, 銅パイプ法 ${ }^{16)}$, inner-metal center-air ratio 法(IMCAR 法 $)^{17)}$ といった方法が報告 されてきた。これらの方法はすべて，X線管が回転し ている状態でX線を照射(回転照射) し, 実効エネル ギーを測定することが可能であるが, 電離箱線量計を 用いた測定を対象としており, 非接続形 X 線出力ア ナライザ Piranha(RTI 社製)を用いた測定には対応し ていなかった。このため,これまで Piranhaを用いて $\mathrm{CT}$ 装置の半価層測定 ( $\mathrm{CT}$ 半価層測定)を行う場合, メンテナンスモードによる固定照射が必要であった。 電離箱線量計と比較した場合, Piranhaはアルミニウ ム板を用いて減弱曲線を作成する必要がなく, 気圧や 温度による影響が少なく，一回の照射で半価層測定が 可能であり，無線で personal computer $(\mathrm{PC})$ と接続し たデー夕転送が可能であるなど，優れた点が多い ${ }^{18,199}$. もし, Piranha を用いた回転照射によるCT 半価層測 定が可能となれば, CT 装置の線質評価が簡易に効率 よく実行することができる。

本研究では, Piranhaを用いた回転照射によるCT 半価層測定を可能とする Piranha 専用鉛ケースを開発 したので報告する.

\section{1. 方 法}

\section{1-1 使用機器}

本研究では, X 線 CT 装置として東芝メディカルシ ステムズ社製 Aquilion CX (64 列)を用い, 線量計とし
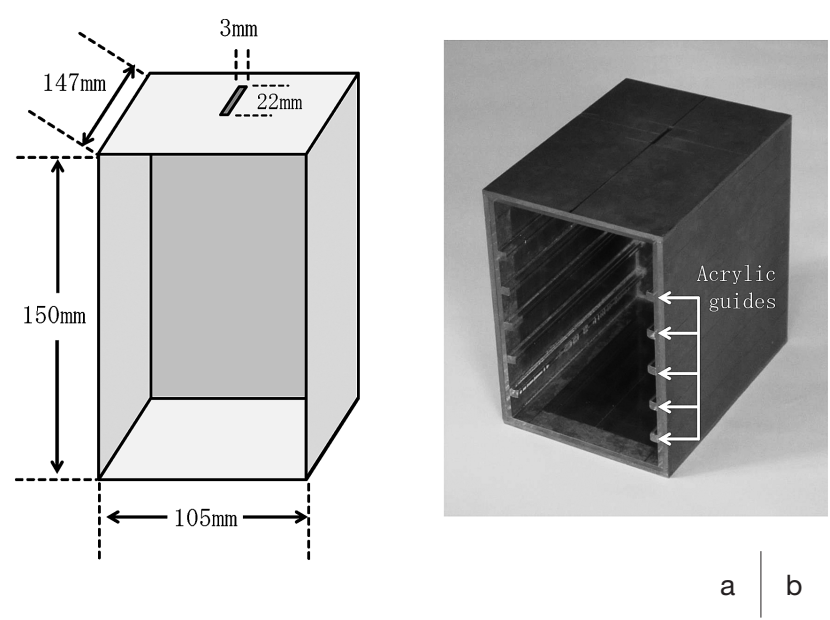

Fig. 1 Design (a) and photograph (b) of the lead-covered case. The lead-covered case was manufactured from acrylic and lead plates, which are $3 \mathrm{~mm}$ thick and have a slit.

て Radcal 社製の電離箱線量計 (model20X6-3CT) 㧍よ びRTI 社製の非接続形 X 線出力アナライザ Piranha （R\&F/M657）を使用した。 Piranhaはシリコン素材の PIN フォトダイオードを用いた半導体線量計である. 検出器の実効中心は表面下 $10 \mathrm{~mm}$ にあり, $3 \times 21 \mathrm{~mm}$ の実効面積内に $3 \times 3 \mathrm{~mm}$ の半導体検出器が複数並ぶ 内部構造となっている ${ }^{18,19)}$. 半導体検出器の表面には 厚さの異なるフイル夕が配置されており，それぞれの フィルタを通して減弱したX $\mathrm{X}$ 線を各検出器で検出し, それらの信号比から自動的に半価層が計算される仕組 みとなっている ${ }^{19)}$.このため, 1 回の照射で半価層を 測定することが可能である (Quick-HVL 測定)。鉛 ケースの材料は, 鉛板として厚さ $3 \mathrm{~mm}$, 純度 $99.99 \%$ 以上の純鉛板 (ヨシザワ LD 社製)，アクリル板として 厚さ $3 \mathrm{~mm}$ のメタクリル樹脂押出板コモグラス(クラ レ社製)を使用した。

\section{1-2 鉛ケースの作成}

鉛ケースは， 0 時方向のみにスリットを開けたケー スの内部に線量計を配置することによって，0 時方向 以外の各方向から照射されるX線を遮蔽できる構造 となっている. 鉛ケースの寸法は Fig. 1 に示すとおり である. $3 \mathrm{~mm}$ 厚のアクリル板を溶接して骨組みを作 り，その外側に $3 \mathrm{~mm}$ 厚の鉛板を接着することで鉛 ケースを作成した。なお，本研究の予備実験として 3 $\mathrm{mm}$ 厚の鉛板で $360^{\circ}$ 全方向を遮蔽した鉛ケースを用 いて回転照射を行った結果, Piranhaの検出限度以下 まで X線を低減可能であることを確認しており，3 $\mathrm{mm}$ 厚の鉛板は十分な遮蔽能力を有する。一般的な 

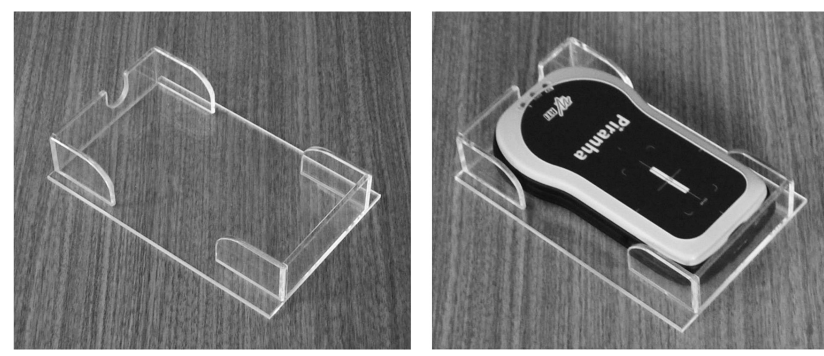

$a \mid b$

Fig. 2 Photographs of the acrylic stand.

(a) Without Piranha

(b) With Piranha

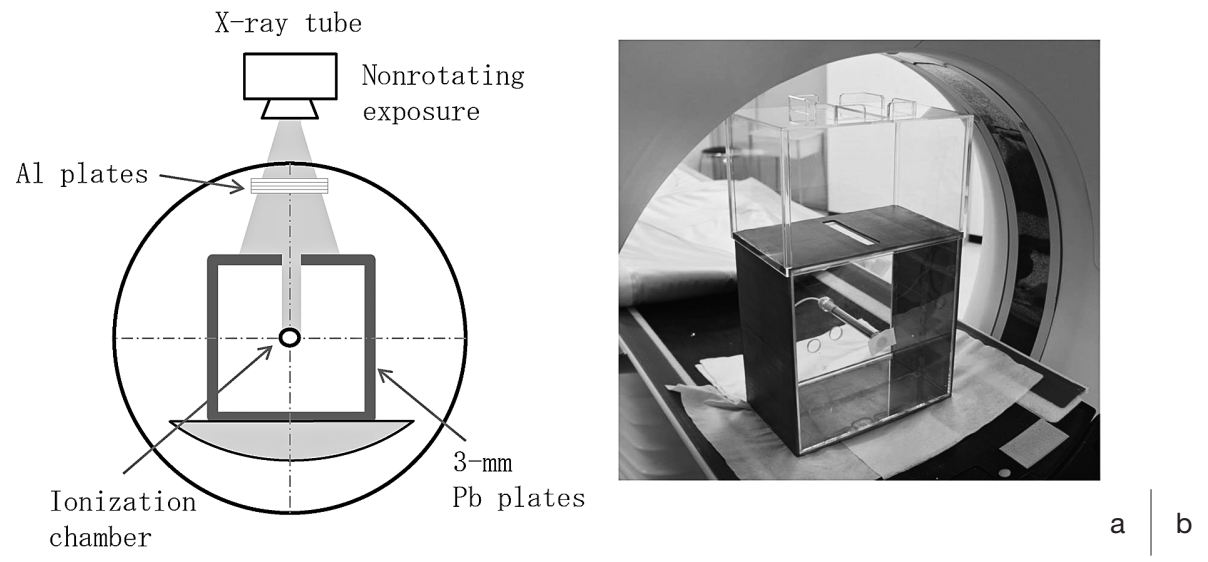

Fig. 3 Arrangement (a) and photograph (b) of the nonrotating method. The size of the lead-covered case was $25 \times 25 \times 15 \mathrm{~cm}$.

$\mathrm{CT}$ 半価層測定用の鉛ケース (電離箱線量計専用) ${ }^{12)}$ の 場合，鉛ケース内部に発泡スチロールを詰めることで 鉛板を支持しているため，発泡スチロールによる X 線の減弱や散乱の影響が懸念されるが, 本研究ではア クリル板の骨組みにより鉛板を支持することで鉛ケー ス内部の空洞化を実現したため，それらの影響が全く ない設計となっている。また，鉛板は他の金属板と比 べ柔らかいため一定の形状を保つことが難しく，歪み や位置ずれ等の変形が起こりやすい，当施設では，鉛 板を回転式リードバイスによって平面状に整形したう えで，電動丸鋸で必要な寸法に切断し，アクリル骨組 みの平面部分に接着することで, 歪みや位置ずれを防 止し，耐久性を確保している。スリットの寸法は Fig. 1 のおり $3 \times 22 \mathrm{~mm}$ であり, Piranhaの検出素子 の実効面積を考慮し設定している。アクリル板および 鉛板にスリットを加工する際は，卓上ボール盤と電動 糸鋸盤を用いた。また，Piranha を設置する高さを調 整するため, 鉛ケース内部には, アクリルガイドを設 置し，鉛ケースのスリット部分から Piranhaの検出器 実効中心までの距離 (スリット検出器間距離)を 14 , 36, 58, 80, 102, $122 \mathrm{~mm}$ の 6 段階で調節可能な設計 とした. Piranhaをセットするアクリルスタンドは,
Fig. 2 に示すように Piranha に位置ずれがないように 設計した。

\section{1-3 測定および評価方法}

本研究では，X線管を固定した状態で電離箱線量計 を用いて半価層を測定する方法(固定照射法)と, $X$ 線 管が回転している状態で Piranha を用いて半価層を測 定する方法(回転照射法)により半価層を測定し比較, 検討を行った。また，これらの方法で得られた半価層 から質量減弱係数を算出し, 質量減弱係数データベー スおよびデータ検索ソフトウェア $\mathrm{mu}-4^{20)}$ に入力する ことで実効エネルギーを求めた.

管電圧は 80, $100,120 \mathrm{kV}$ とし, 管電流は固定照射 法では $200 \mathrm{~mA}$, 回転照射法では十分な線量を得るた め $550 \mathrm{~mA}$ に設定した。また，照射時間は 1 秒，回転 照射法ではノンヘリカルスキャンモードで回転速度を $1 \mathrm{~s} /$ rot.とした。 ビーム幅は $32 \mathrm{~mm}$, 焦点サイズは L (1.6×1.4 mm)，ボウタイフィルタは S とした。

\section{1-3-1 固定照射法}

幾何学的配置は Fig. 3 に示すとおりで，ガントリ中 心に電離箱線量計の実効中心が位置するように配置 し, メンテナンスモードから X 線管を 0 時方向に固 

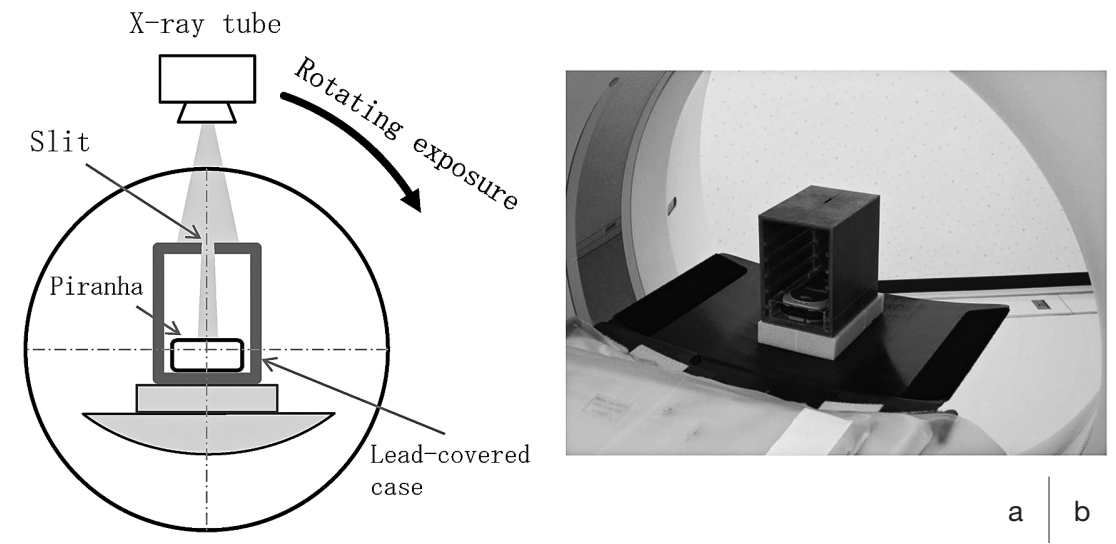

Fig. 4 Arrangement (a) and photograph (b) of the rotating method.

定した状態で照射を行った。厚さ $3 \mathrm{~mm}$ の鉛板を電離 箱線量計の周囲に配置し, 0 時方向に開口幅 $2 \mathrm{~cm}$ の スリットを開口することで，ガントリ内外からの散乱 線を遮蔽した。また，アルミニウム板は JIS 合金番号 1105(純度 99.5\%以上)のものを使用した。アルミニウ ム板の厚さを変化させながら, 各厚さに拈いて照射線 量を 5 回ずつ測定し，それらの平均值を用いてアルミ ニウム減弱曲線を作成することにより半価層を得た。

\section{1-3-2 回転照射法}

幾何学的配置は Fig. 4 に示すと抢りで，スリット検 出器間距離を 6 段階調整しながら，それぞれのスリッ 卜検出器間距離において Piranha の実効中心がガント リ中心に位置するように寝台の高さを調整した，鉛ケー 久を用いて 0 時方向の X 線のみが Piranha の検出器 部分に入射するように配置した状態で回転照射を行っ た、測定は Piranhaの Quick-HVL 測定機能を使用し て, 各条件で 5 回半価層を求め, 一番大きい值と一番 小さい值を除いた三つの值の平均值を半価層の測定值 とした。各スリット検出器間距離における半価層の測 定值を固定照射法の測定值と比較することで，スリッ ト検出器間距離が測定精度に及ぼす影響を検証した。

\section{2. 結 果}

固定照射法における半価層と実効エネルギーの測定 結果を Table 1 に, 回転照射法に扔ける半価層と実効 エネルギーの測定結果を Table 2 に示す。また, Table 3 に回転照射法で得た半価層および実効エネル ギーの固定照射法に対する絶対誤差および相対誤差を 示す，回転照射法で得た半価層および実効エネルギー の值は, 固定照射法と比較して小さい值を示す傾向が あった。また, スリット検出器間距離が短い場合, 誤 差が大きい結果となったが, 距離を長くすることで固
Table 1 Results for half-value layers (HVLs) and the effective energy obtained from the nonrotating method

\begin{tabular}{ccc}
\hline \hline $\begin{array}{c}\text { Tube voltage } \\
(\mathrm{kV})\end{array}$ & $\begin{array}{c}\text { HVL } \\
(\mathrm{mmAl})\end{array}$ & $\begin{array}{c}\text { Effective energy } \\
(\mathrm{keV})\end{array}$ \\
\hline 80 & 4.38 & 39.5 \\
100 & 5.51 & 44.3 \\
120 & 6.61 & 48.6 \\
\hline
\end{tabular}

Table 2 Results for half-value layers (HVLs) and the effective energy obtained from the rotating method

\begin{tabular}{cccc}
\hline $\begin{array}{c}\text { Tube voltage } \\
(\mathrm{kV})\end{array}$ & $\begin{array}{c}\text { Slit-detector } \\
\text { distance } \\
(\mathrm{mm})\end{array}$ & $\begin{array}{c}\text { HVL } \\
(\mathrm{mmAl})\end{array}$ & $\begin{array}{c}\text { Effective } \\
\text { energy } \\
(\mathrm{keV})\end{array}$ \\
\hline 80 & 14 & 3.97 & 37.9 \\
& 36 & 4.21 & 38.9 \\
& 58 & 4.24 & 39.0 \\
& 80 & 4.24 & 39.0 \\
& 102 & 4.23 & 38.9 \\
100 & 122 & 4.22 & 38.9 \\
& 14 & 4.96 & 42.0 \\
& 36 & 5.32 & 43.5 \\
& 58 & 5.37 & 43.7 \\
& 80 & 5.37 & 43.7 \\
& 102 & 5.39 & 43.8 \\
& 122 & 5.35 & 43.6 \\
& 14 & 5.99 & 46.2 \\
& 36 & 6.36 & 47.7 \\
& 58 & 6.48 & 48.2 \\
& 80 & 6.54 & 48.4 \\
& 102 & 6.56 & 48.4 \\
& 122 & 6.61 & 48.6 \\
\hline
\end{tabular}

定照射法に近い值が得られるようになり, $58 \mathrm{~mm}$ 以上 に設定した場合，半価層の誤差は 0.001 $0.160 \mathrm{mmAl}$ (0.01〜3.65\%)，実効エネルギーの誤差は 0.003〜0.651 $\mathrm{keV}(0.01 \sim 1.55 \%)$ であった. 
Table 3 The differences in HVLs and effective energy between the nonrotating and the rotating methods

\begin{tabular}{cccccc}
\hline \hline $\begin{array}{c}\text { Tube voltage } \\
(\mathrm{kV})\end{array}$ & $\begin{array}{c}\text { Slit-detector } \\
\text { distance } \\
(\mathrm{mm})\end{array}$ & $\begin{array}{c}\text { HVLs } \\
\text { difference } \\
(\mathrm{mmAl})\end{array}$ & $\begin{array}{c}\text { HVLs } \\
\text { error } \\
(\%)\end{array}$ & $\begin{array}{c}\text { Effective } \\
\text { energy } \\
\text { difference } \\
(\mathrm{keV})\end{array}$ & $\begin{array}{c}\text { Effective } \\
\text { energy } \\
\text { error } \\
(\%)\end{array}$ \\
\hline 80 & 14 & 0.407 & 9.28 & 1.583 & 4.01 \\
& 36 & 0.167 & 3.81 & 0.638 & 1.62 \\
& 58 & 0.137 & 3.12 & 0.522 & 1.32 \\
& 80 & 0.137 & 3.12 & 0.522 & 1.32 \\
100 & 102 & 0.150 & 3.42 & 0.574 & 1.45 \\
& 122 & 0.160 & 3.65 & 0.612 & 1.55 \\
& 14 & 0.547 & 9.92 & 2.314 & 5.22 \\
& 36 & 0.187 & 3.39 & 0.777 & 1.75 \\
& 58 & 0.140 & 2.54 & 0.581 & 1.31 \\
& 80 & 0.140 & 2.54 & 0.581 & 1.31 \\
& 102 & 0.123 & 2.24 & 0.512 & 1.16 \\
& 122 & 0.157 & 2.84 & 0.651 & 1.47 \\
& 14 & 0.624 & 9.44 & 2.414 & 4.96 \\
& 36 & 0.254 & 3.84 & 0.969 & 1.99 \\
& 58 & 0.127 & 1.93 & 0.484 & 0.99 \\
& 80 & 0.068 & 1.02 & 0.257 & 0.53 \\
& 102 & 0.051 & 0.77 & 0.192 & 0.39 \\
& 122 & 0.001 & 0.01 & 0.003 & 0.01 \\
\hline
\end{tabular}

\section{3. 考 察}

本研究では CT 装置の半価層および実効エネルギー 測定において，Piranha と鉛ケースを用いた回転照射 法の測定値を固定照射法と比較し, 精度の検証を行った.

80, 100, $120 \mathrm{kV}$ のいずれの管電圧においても，回 転照射法で得られた半価層および実効エネルギーが固 定照射法と比較して小さい值となる傾向があった。こ れは，X線管からの直接 X 線だけでなく，鉛ケースの スリット部分から発生した散乱線が Piranha の検出器 部分に入射し，低エネルギー成分が増加したためと考 えられる，特に，スリット検出器間距離が最も短い 14 $\mathrm{mm}$ の場合, 半価層の相対誤差は最大 $9.9 \%$, 実効エネ ルギーの相対誤差は最大 $5.2 \%$ となり，差異が大きい 結果となった。しかし，スリット検出器間距離を増加 させることで精度が改善され，スリット検出器間距離 を $58 \mathrm{~mm}$ 以上に設定した場合，実効エネルギーの相 対誤差は 80, $100 \mathrm{kV}$ において $2 \%$ 未満, $120 \mathrm{kV}$ にお いて $1 \%$ 未満となり，固定照射法と同等な值を得るこ とができた。この要因としては，スリット検出器間距 離を離すことによって，スリット部分から発生した散 乱線の, 検出器部分まで到達する量が減少したことが 考えられる。更に，スリット検出器間距離を $58 \mathrm{~mm}$ より大きい值に設定すると，120 kVにおいては徐々 に精度が改善したが, 80, $100 \mathrm{kV}$ においては大きな変 化はなく改善が認められなかった。 よって, $120 \mathrm{kV}$
においてはスリット検出器間距離 $58 \mathrm{~mm}$ の時点で実 効エネルギーの相対誤差が $1 \%$ 未満と十分な精度で測 定することができていることと，80, $100 \mathrm{kV}$ において は $58 \mathrm{~mm}$ 以降でスリット検出器間距離の増加に伴う 精度の改善が認められなかったことから, 必要最小限 のスリット検出器間距離は $58 \mathrm{~mm}$ であると考える.

また，電離箱線量計における鉛ケースを用いた回転 照射法と固定照射法の実効エネルギーの誤差について は，松原ら ${ }^{14)}$ の報告では $0.1 \sim 0.3 \mathrm{keV}(0.2 \sim 0.7 \%)$, 近 藤ら ${ }^{15)}$ の報告では $0.0 \sim 0.6 \mathrm{keV}(0.0 \sim 1.1 \%)$ とされて いる. 本研究ではスリット検出器間距離 $58 \mathrm{~mm}$ に設 定することで Piranha を用いた回転照射法と固定照射 法の実効エネルギーの誤差は $0.5 \sim 0.6 \mathrm{keV}(1.0 \sim$ $1.3 \%)$ となり, 電離箱線量計に打ける先行研究と同等 な結果が得られた。これらのことから, 本研究で自作 した，スリットサイズが $3 \times 22 \mathrm{~mm}$ の Piranha 専用鉛 ケースを用いて適切な遮蔽を行うことによって, Piranhaにおいても回転照射法を用いた半価層および 実効エネルギーの測定が可能であると考える.

一般的な $\mathrm{CT}$ 半価層測定用の鉛ケース (電離箱線量 計専用 $)^{12)}$ を実際に作成した場合, 重量は 6 7 kg 程 度となる。実験時の作業負担を軽減し利便性を保つた めには少しでも軽いことが望ましい，また，強度の面 でも鉛板の面積が増加すると, 厚さ $3 \mathrm{~mm}$ のアクリル 板で作成した骨組みにかかる負担が増加し，耐久性が 


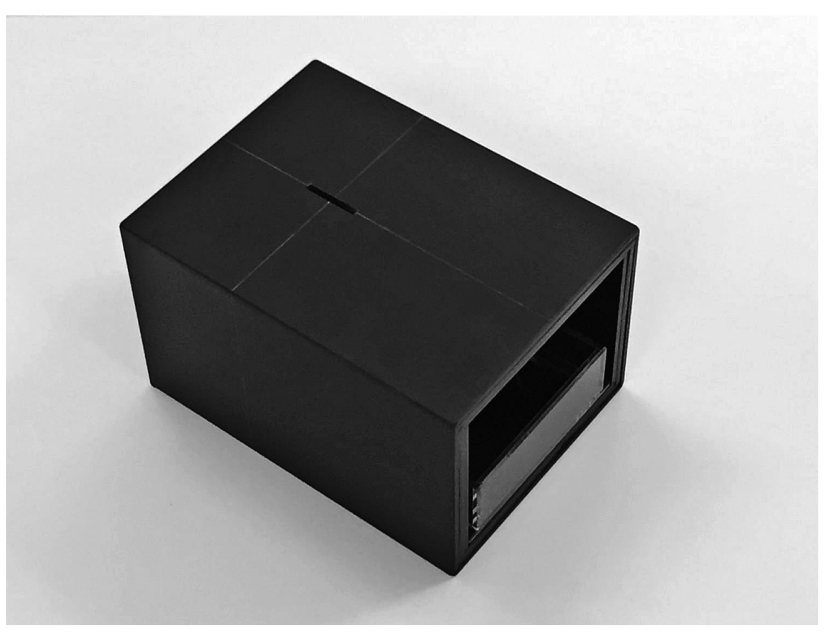

Fig. 5 Photograph of the lead-covered case which is optimized for sale.

低下する可能性がある。これらの観点から, 鉛ケース のコンパクト化は重要であり, スリット検出器間距離 を必要最小限の $58 \mathrm{~mm}$ に最適化したコンパクトな鉛 ケースを作成することで，利便性，耐久性の向上，お よび材料費の低減が可能と考える。実際にスリット検 出器間距離を $58 \mathrm{~mm}$ に最適化した鉛ケース(Fig. 5)を 作成したところ, 重量は $2.6 \mathrm{~kg}$ となり電離箱線量計用 鉛ケースの 6〜 $7 \mathrm{~kg}$ と比較して半分以下の重量に抑え ることができた。

鉛ケースの材料として用いた厚さ $3 \mathrm{~mm}$ の鉛板は, 加工が容易であり丸鋸や糸鋸などの工作用設備を所有 していれば鉛ケースを自作することができる，工作用 設備が整っておらず，自作することが困難な場合は， 当施設で製造した製品版鉛ケース (Fig. 5)をアクロバ イオ社から購入することも可能である。この製品版鉛 ケースは, 本研究の成果をアクロバイオ社に提供した ものであり, スリット検出器間距離についても本研究 で最適と判断した $58 \mathrm{~mm}$ に設定して製品化している. よって, Piranha を所有している施設においては鉛 ケースを自作もしくは購入することで，メンテナンス モードを必要としない回転照射法による CT 半価層測 定が可能となった。

電離箱線量計を用いた鉛ケース法12,14,15) の場合, ア ルミニウム減弱曲線を作成するため, アルミニウム板 の厚さを変化させ，その度に複数回の照射が必要とな り, CT 装置のX線管にかかる負荷は多くなる。本研 究のPiranha と鉛ケースを用いた回転照射法では, Piranha の Quick-HVL 測定機能を利用することで，1 回の照射で半価層を測定することが可能であり，X 線 管負荷の低減につながると考えられる。しかし，
Piranhaの Quick-HVL 測定機能を利用する場合, Piranha の有効感度領域すべてにX 線を入射させる必 要があるため, ビーム幅の設定に注意する必要があ る。また，数秒間に複数回 X 線が入射した場合，間欠 照射により Piranha が誤作動を起こす可能性があるた め, X 線管の回転数を 1 回転に設定し, Piranhaへの $\mathrm{X}$ 線の入射を 1 回に制限する必要がある。

本研究では，管電圧を $80,100,120 \mathrm{kV}$ に限定して おり, $135 \mathrm{kV}$ や $140 \mathrm{kV}$ といった高管電圧における検 証は行っていない。これは, 当施設で所有している Piranha が初期型のものであり, Quick-HVL 測定機能 で精度が保証されている管電圧の範囲が 60 120 kV となっているためである。しかし，近年新たに発売さ れた Piranhaの後継機 Black Piranhaに扔いては, Quick-HVL 測定機能の精度保証される管電圧範囲が 45〜160 kV と広範囲になっているため, 高管電圧に おける半価層測定が可能である。本研究結果より, $120 \mathrm{kV}$ においてスリット検出器間距離が長くなるに つれて精度の改善が認められたことから，120 kVよ り高い管電圧においては最適なスリット検出器間距離 が $58 \mathrm{~mm}$ より大きくなる可能性があるため, 今後, Black Piranha を使用する機会があれば, $135 \mathrm{kV}$ や $140 \mathrm{kV}$ といった高管電圧に扔ける検証も行っていき たい.

\section{4. 結 語}

本研究では Piranha を用いた回転照射によるCT 半 価層測定を実現するため, Piranha 専用鉛ケースを作 成し, スリット検出器間距離を変化させて精度の検証 を行った。スリット検出器間距離を $58 \mathrm{~mm}$ 以上に設 定することで，固定照射法と同等の精度で測定可能で あることが明らかになった。これによって，メーカ協 力のもとメンテナンスモードから X 線管を固定する 必要がなくなり, Piranha を所有する施設においては, CT 半価層測定を行うことが容易となった，今後，こ の手法が普及し，CT装置に扔ける線質評価の一助と なることを期待する。

\section{謝 辞}

本研究は, 北海道支部の平成 26 年度放射線技術研 究の助成を受けて行われました。ここに厚くお礼申し 上げます。

なお，本研究の要旨は, 第 42 回日本放射線技術学会 秋季学術大会 (2014 年 10 月, 札幌)にて発表した. 


\section{参考文献}

1) Gonzalez AB, Darby S. Risk of cancer from diagnostic X-rays: estimates for the UK and 14 other countries. Lancet 2004; 363 (9406): 345-351.

2）岡崎龍史, 大津山彰, 阿部利明, 他. 福島県内外の一般市 民および医師の福島第一原子力発電所事故後の放射線被 曝に対する意識調査．産業医科大学雑誌 2012；34(1)：91105 .

3）赤羽恵一．医療被ばくの現状．Innervision 2010；25(6)：4649.

4) IAEA. International basic safety standards for protection against ionizing radiation and for the safety of radiation sources. Vienna, IAEA SAFETY SERIES No115, 1996.

5) ICRP publication87. Managing patient dose in computed tomography. Annals of the ICRP, 2000.

6) Huda W, Ogden KM, Khorasani MR. Converting dose-length product to effective dose at CT. Radiology 2008; 248(3): $995-$ 1003

7) AAPM Report No. 204. Size-specific dose estimates (SSDE) in Pediatric and adult body CT examinations, 2011.

8）松原孝祐，越田吉郎，鈴木正行，他．X 線 CT 装置間での 線量プロファイルおよび患者被ばく線量の比較評価。日 放技学誌 2005; 61(5): 683-690.

9）橘 昌幸，泉 隆．X線スペクトルによる吸収線量変換 係数：半価層による方法との比較. 日放技学誌 $2002 ; 58$ (3): 383-389.

10）小山修司。診断領域 $\mathrm{X}$ 線の線量測定のキーポイント，日 放技学誌 2000; 56(7): 909-918.

11）大釜 昇. 診断領域 $\mathrm{X}$ 線の実効エネルギー測定．日放技 学誌 2001; 57(5): 550-556.
12）日本放射線技術学会計測分科会編。医療被ばく測定テキ ス卜。放射線医療技術学叢書 $(25)$. 日本放射線技術学会, 京都, 2012: 55-72.

13) Kruger RL, McCollough CH, Zink FE. Measurement of halfvalue layer in $\mathrm{x}$-ray $\mathrm{CT}$ : a comparison of two noninvasive techniques. Med Phys 2000; 27(8): 1915-1919.

14) Matsubara K, Ichikawa K, Murasaki Y, et al. Accuracy of measuring half- and quarter-value layers and appropriate aperture width of a convenient method using a lead-covered case in X-ray computed tomography. J Appl Clin Med Phys 2014; 15(1): 4602.

15）近藤博仁, 松原孝祐, 廣澤文香, 他. $\mathrm{X}$ 線 $\mathrm{CT}$ 装置に扮け る簡便化された各種実効エネルギー評価法の比較。日放 技学誌 2014; 70(5): 453-460.

16）飯田泰治, 能登公也, 三井 涉, 他. 銅製パイプ型吸収体 を用いた新しい実効エネルギー測定法. 日放技学誌 2011; 67(9): 1183-1191.

17）長島宏幸, 須永眞一, 見留豊久, 他. $\mathrm{X}$ 線 CT 装置の線量 評価に不可欠な実効エネルギーの新たな測定および算出 法の検討。日放技学誌 2005; 61(3): 385-391.

18）猪岡由行, 有賀英司, 西尾直美, 他. 非接続形 $\mathrm{X}$ 線出力厂 ナライザの精度評価。日放技学誌 2013; 69(10): 1153-1160

19）古畑 優. 無線式アナライザーPiranhaについて：半導体 検出器の構造と原理ならびに Piranha の特徵。日本診療 放射線技師会誌 2014; 61(8): 933-935.

20）加藤秀起. 光子の物質に対する質量エネルギー転移係数. 日放技学誌 2014; 70(7), 684-691. 